\title{
Value chains, networks and clusters: reframing the global automotive industry
}

\author{
Timothy Sturgeon* ${ }^{\dagger \dagger}$, Johannes Van Biesebroeck** and Gary Gereffi***
}

\begin{abstract}
In this article, we apply global value chain (GVC) analysis to recent trends in the global automotive industry, with special attention paid to the case of North America. We use the three main elements of the GVC framework-firm-level chain governance, power and institutions - to highlight some of the defining characteristics of this important industry. First, national political institutions create pressure for local content, which drives production close to end markets, where it tends to be organized nationally or regionally. Second, in terms of GVC governance, rising product complexity combined with low codifiability and a paucity of industry-level standards has driven buyer-supplier linkages toward the relational form, a governance mode that is more compatible with Japanese than American supplier relations. The outsourcing boom of the 1990s exacerbated this situation. As work shifted to the supply base, lead firms and suppliers were forced to develop relational linkages to support the exchange of complex uncodified information and tacit knowledge. Finally, the small number of hugely powerful lead firms that drive the automotive industry helps to explain why it has been so difficult to develop and set the industry-level standards that could underpin a more loosely articulated spatial architecture. This case study underlines the need for an open, scalable approach to the study of global industries.
\end{abstract}

Keywords: Automobiles, global value chains, networks, clusters, governance, institutions JEL classifications: L23, L62, F15, R11

Date submitted: 6 November 2007 Date accepted: 11 February 2008

\section{Introduction ${ }^{1}$}

Making sense of how the global economy is evolving is a difficult task. Better theoretical and methodological tools are urgently needed to analyze the complex web of influences, actions and feedback mechanisms at work. As national and local economies, and the firms and individuals embedded in them have come into closer contact through trade and foreign direct investment, the complexity of the analytical problem has increased. The classic tools of economics, especially theories of supply and demand and national comparative advantage, while powerful and astonishingly predictive,

${ }^{\dagger}$ Corresponding author: email <sturgeon@mit.edu>

*MIT.

**University of Toronto.

$* * *$ Duke University.

1 This article is based, in part, on research funded by Doshisha University's ITEC 21st Century COE (Centre of Excellence) Program (Synthetic Studies on Technology, Enterprise and Competitiveness Project). Comments provided by Peter Dicken and two anonymous reviewers were extremely helpful. All responsibility for the content lies with the authors. 
have always been too thin and stylized to explain all of the richness of industrial development and economic life, and correctives have been coming from fields such as economic sociology, management, economic geography and political science for many decades.

Institutions - labor unions, industry associations, legal and cultural norms, industryspecific standards and conventions, etc.- matter. The rules set by states and multilateral organizations matter. Firms can have substantial power within their respective industries, and wield it to advance their positions in a variety of ways. Managers, workers and consumers have agency and can act individually or in groups to change outcomes. Individuals are not simply managers, consumers and workers, but men and women with complex identities and a wide variety of motivations and roles in society. To make matters even more complex, both the tug and flow of place and history continually shape and reshape what can be observed on the ground at any given moment. Events are almost always, to some degree, constrained by path dependence and determined by feedback loops of both the positive and negative kind.

Debates about what, precisely, shapes outcomes in the spatial economy are ongoing and very useful, but we appear to be a critical juncture where rising complexity from global integration has begun to overwhelm the slow and partial analytical progress that has been made in the past 25 years. As researchers begin to probe the most recent aspects of global integration, such as how American, Japanese, Korean and Taiwanbased firms interact with each other and with local firms to produce Apple iPods in southern China for export to world markets (Linden et al., 2007), then some of the core assumptions of mainstream economics - that demand begets supply, that nations draw only on their own resources to compete with other nations, that exports reflect the industrial performance of the exporter, that national and international institutions do not matter, that firms and individuals act independently, rationally and at arms-length, and so on - appear as quaint reminders of simpler times. But if the tools of mainstream economics are being blunted by global integration, so too are those offered by other social science disciplines, which typically assume levels of institutional, cultural and geographic cohesiveness and autarky that no longer exist.

How, then, are we to wade through the morass of influences, tendencies and causes that structure empirical outcomes in the global economy? If global integration will lead to institutional and strategic convergence, as some believe it will, then seeking larger patterns could be a waiting game. However, the specificities of institutions, culture and industry are clearly not eliminated by globalization, but brought into intensified contact, triggering a process of accelerated change that leads to increasing diversity over time (Sturgeon, 2007). The result is a rich and roiling stew of causation and outcome that is extremely difficult to penetrate, both analytically and methodologically.

The concept of global value chains (GVCs) provides a pragmatic and useful framework as we seek answers to questions about the dynamic economic geography of industries. ${ }^{2}$ GVC analysis highlights three features of any industry: (i) the geography and character of linkages between tasks, or stages, in the chain of value added activities; (ii) how power is distributed and exerted among firms and other actors in the chain and (iii) the role that institutions play in structuring business relationships and

2 See www.globalvaluechains.org for more detail on this approach and a list of publications and researchers that directly engage with it. 
industrial location. Each of the three elements can contribute to explanations of how industries and places evolve, and provide insight into how they might evolve in the future. The chain metaphor is purposely simplistic. It focuses us on the location of work and the linkages between tasks as a single product or service makes its way from conception to end use, not because this chain of activity occupies the whole of our interest, but because it provides a systematic and parsimonious way to begin the research process.

In this article, we use GVC analysis to explore trends in the automotive industry, with special attention paid to the case of North America. In Section 2, we trace debates in economic geography that have progressed from cluster-centered analysis of social, industrial and institutional development, to a vision of global-scale networks of interlinked clusters. In Section 3, we sketch a broad overview of the organizational and spatial structure of the global automotive industry. In subsequent sections, we use the three main elements of the GVC framework-inter-firm governance, power and institutions - to explain a few of the key competitive and geographic features of this important industry.

\section{On clusters, networks and value chains}

While the tension between the centrifugal and centripetal tendencies of capitalism has been theorized as a fundamental characteristic of economic development (Storper and Scott, 1988; Storper and Walker, 1989), the central focus of geographers has been the structuring role of place. For geographers, the industrial histories, social organization and institutions of specific places matter. They enable and set limits on what is possible and help to structure what comes next through the processes of agglomeration, increasing returns and path dependence. Path dependence is accentuated in dense social networks because actors are likely to deepen ties with partners that they have the most interactions with, especially if those ties are diverse in character and involve trust (Glückler, 2007, 625).

As Martin and Sunley (2006) argue, such network features are created and reinforced by geographic proximity and as a result, economic activity often has an important local dimension. Firms tend to discount distant resources, even when access to them might be beneficial, and gravitate toward the network and governance structures they inherit from the local environment. Specialized labor markets and exchanges of tacit knowledge are especially dense, efficient and vibrant when it is possible for agents to meet face to face (Storper, 1995). Localization is important in the creation of new knowledge because innovative work necessarily involves the generation and exchange of knowledge that has not been rendered portable through codification. Since change in spatially embedded networks is slow, history matters, as well as geography, and this further ties sector-specific knowledge and innovative activity to particular places (Malmberg and Maskell, 1997, 27).

While these are important arguments, one is led to question if economic geography's focus on the local has hobbled the field in its analysis of globalization. The processes of dispersal are not confined to the re-location of economic activity to some newly dynamic center where the agglomeration process can begin anew (Storper and Walker, 1989), but also include the unfolding — and perhaps historically novel — dynamics that are presently driving deep functional integration across multiple clusters (Dicken, 2003, 12), a process we refer to as global integration. 
As important as agglomeration and localized innovation remain, the forces of dispersal and global integration are also on the march, and this exposes the weak analytical and methodological tools that economic geographers have developed to tackle the important questions posed by global integration. ${ }^{3}$ More recently, the field of economic geography has begun to address these questions with greater balance and sophistication. Instead of continuing to argue for the primacy of clustering and agglomeration over fragmentation and footlooseness, the focus has shifted to reconciling the apparently contradictory forces of clustering and dispersal. A number of recent papers, such as Wolfe and Gertler (2004) and Hansen (2008), focus on how long distance linkages can work to strengthen clusters and how cluster-based firms exploit locality-derived advantages when they expand overseas.

A starting point for this strand of the geography literature has been the simple yet powerful - and quite venerable - notion that tacit information and knowledge are best developed and exchanged locally, while codified information and knowledge can be transferred and linked in national- or international-scale networks (Scott, 1988; Malmberg and Maskell, 1997). In this vision, clusters can be quite specialized if linked to other specialized clusters through the exchange of codified information and knowledge. While this resonates with the empirical evidence, more recent work has begun to move beyond the local-tacit/global-codified dichotomy by pointing out that tacit knowledge is not always created and exchanged locally. Gertler (2003) began this discussion by 'unpacking' the 'problem' of tacit knowledge into three challenges that firms face: (i) creating it, (ii) finding and appropriating it and (iii) moving it once it has been appropriated. His argument is that the first problem is best solved with proximity and the supporting institutions of place, and that the second and third problems are extremely difficult, time-consuming and costly to achieve because they inevitably involve the long distance transfer of tacit knowledge.

Bathelt et al. (2004) point out that companies and individuals actively seek solutions to these problems by building 'pipelines' to transmit uncodified information and tacit knowledge across clusters. In this view, tacit and codified information can be exchanged locally or globally, although the more spontaneous and serendipitous linking of tacit information - the 'buzz' of the industrial district - tends to remain highly localized. External pipelines can have an organizational dimension, in the establishment of subsidiaries or through the build-up of trust- or performance-based inter-firm relationships, as well as an interpersonal dimension, embodied by the routine travel and relocation of engineers and managers (Saxenian, 2006), and increasingly, though the use of advanced communications technologies such as 'telepresence' or 'rich teleconferencing' systems. Pipelines can also have an institutional dimension, in 'communities of interest' that convene online, or in person at regularly planned professional meetings and conferences. The firms that create or tap into such pipelines feed their home clusters with fresh ideas, which tend to spill over to firms that may not have direct external linkages. The best performing clusters are those that are well connected to critical outside technical and market information, but not so densely linked that local networks become diluted and ineffective.

3 Indeed, Dicken (2004) has gone so far as to suggest that globalization constitutes a 'missed boat' for the field. Who, if not geographers, should be shaping our collective notions of globalization? 
As we can see, the field of economic geography has begun to enlarge its analysis of spatial clustering to encompass questions related to global integration. Economic activity is organized as a web of more or less specialized industrial clusters that are becoming increasingly interlinked over time. As new clusters arise and old clusters create global linkages, the variety, density and geographic scope of functionally linked economic activity is increasing in scale and scope. Linkages within clusters, because of social and spatial proximity, are extremely rich and efficient, while linkages between clusters are worth the effort because they provide access to novel information and resources not available within the cluster.

While this seems straightforward enough, an imbalance remains in the realm of theory. Cluster dynamics have been deeply theorized, but the linkages between clusters have only begun to be examined and discussed in any detail. Local actors can forge external linkages, and these can carry both tacit and codified information; however, the focus remains on how these linkages play out within the cluster, not on the larger economic structures that are created when clusters are woven together. Like Dicken (2005), we find the local-global dichotomy that lies at the heart of the economic geography literature useful but ultimately unsatisfactory. What is needed is an open analytical framework that can accommodate the full range of forces, actors and spatial scales at work. A comprehensive theory of economic geography should be spatially scalable and comprised of a set of complementary, interlocking, non-exclusive predictive models that can shed light on specific issues.

We hope to accelerate this process of theory building by offering the GVC perspective as a framework for theorizing external linkages that is compatible with the deep theoretical work that has been accomplished by economic geographers in the realm of localization. At this point, most serious research on global integration has been carried out by a diverse, interdisciplinary network of scholars, especially those engaged in direct observational research of a set of global, or globalizing industries, such as electronics, furniture, apparel, horticulture, motor vehicles and commodities such as coffee a cacao (Gereffi, 1994; Borrus et al., 2000; Dolan and Humphrey, 2000; Sturgeon, 2002; Fold, 2002; Kaplinsky et al., 2002; Talbot, 2002; Gibbon, 2003; Gibbon and Ponte, 2005; Berger and the MIT Industrial Performance Center, 2005; Kaplinsky, 2005, 2006), and more recently, services (Dossani and Kenney, 2003). As industry after industry has developed intensifying and often divergent patterns of global integration, such 'industry studies' scholars have found themselves, sometimes quite unintentionally, engaged in the study of global integration. Because these researchers have allowed themselves to be led first and foremost by the empirical evidence, not by theory, a search has emerged for a unifying, open, industry-independent theoretical framework to help identify larger patterns and account for divergent findings.

This work has generated several important insights that bear on themes in the economic geography literature. First, the development, maintenance and transfer of codified information may also require the exchange of baseline tacit information as codification schemes are created, a process that typically occurs in key industry clusters (Sturgeon, 2003). Second, the exchange of codified information is rarely perfect, especially when transactions are very complex, and significant ancillary tacit interactions are commonly required as problems arise. Finally, and perhaps most importantly, locally forged relationships are often projected globally through a process described by Humphrey and Memedovic (2003) as follow sourcing, where large suppliers follow their customers' investments abroad. Such global suppliers can even act as 
proxies for their customers in new locations (Sturgeon and Lester, 2004). Thus, we are reminded that capabilities are bundled within firms, as well as localities, and that local and distant linkages are not mutually exclusive, but part of a nested and increasingly integrated spatial economy that involves cohesion at all spatial scales, local, national, continental and global.

There have been several sustained efforts to systemize observed patterns in global industries, most notably the global production networks (Coe et al., this issue; Dicken et al., 2001; Henderson et al., 2002; Dicken, 2005; Yeung et al., 2006), and GVCs (Gereffi and Kaplinsky, 2001; Gereffi et al., 2005; Sturgeon, forthcoming), approaches. In our view, the value chain metaphor is the more useful heuristic tool for focusing research on complex and dynamic global industries. The chain metaphor is not literal or exclusive. It does not assume a unidirectional flow of materials, finance or intellectual exchange, although a focus on buyer power does encourage researchers to be on the lookout for top-down governance and power asymmetries. A value chain can usefully be conceptualized as a subset of more complex and amorphous structures in the spatial economy, such as networks, webs and grids (Pil and Holweg, 2006). Value chains provide a snapshot of economic activity that cut through these larger structures, while at the same time clearly identifying smaller scale entities and actors, such as workers, clusters, firms, and narrowly defined industries (Sturgeon, 2001). This 'meso-level' view of the global economy provides enough richness to ground our analysis of global industries, but not so much that it becomes bogged down in excessive difference and variation, or is forced into overly narrow spatial, analytic or sectoral frames in response to the overwhelming complexity and variation that researchers inevitably encounter in the field.

As Humphrey and Schmitz (2002) have pointed out, cluster research and theory have focused almost exclusively on the internal governance of localities while conceptualizing external linkages simplistically as either contained within multi-locational firms or made through arms-length trading relationships. GVC research and theory, by contrast, has the opposite geographic focus, but posits a range of governance structures that go beyond the vertically integrated transnational corporations and arms-length crossborder market transactions envisioned by the cluster literature. The theory of governance contained in the GVC framework identifies three intermediate modes of value chain coordination (modular, relational and captive) that are, in part, determined by variables that have been identified by cluster researchers as being important: (i) the complexity of information exchange; (ii) the codifiability of knowledge and (iii) the capabilities resident in the supply-base (Gereffi et al., 2005). The complementary nature of the two streams of scholarship represents an opportunity that we will explore through the case of the automotive industry.

\section{GVCs in the automotive industry: a nested structure}

From a geographic point of view, the world automotive industry, like many others, is in the midst of a profound transition. Since the mid-1980s, it has been shifting from a series of discrete national industries to a more integrated global industry. In the automotive industry, these global ties have been accompanied by strong regional patterns at the operational level (Lung et al., 2004; Dicken, 2005, 2007). Market saturation, high levels of motorization, and political pressures on automakers to 
'build where they sell' have encouraged the dispersion of final assembly, which now takes place in many more places than it did 30 years ago. While seven countries accounted for about $80 \%$ of world production in 1975, 11 countries accounted for the same share in 2005 (Automotive News Market Data Books, various years). The widespread expectation that markets in China and India were poised for explosive growth generated a surge of new investment in these countries.

Consumer preferences sometimes require automakers to alter the design of their vehicles to fit the characteristics of specific markets. ${ }^{4}$ In other places, automakers want their conceptual designers to be close to 'tuners' to see how they modify their production vehicles. These motivations have led automakers to establish a series of affiliated design centers in places such as China and Southern California. Nevertheless, the heavy engineering work of vehicle development, where conceptual designs are translated into the parts and sub-systems that can be assembled into a drivable vehicle, remain centralized in or near the design clusters that have arisen near the headquarters of lead firms. ${ }^{5}$

The automotive industry is therefore neither fully global, consisting of a set of linked, specialized clusters, nor is it tied to the narrow geography of nation states or specific localities as is the case for some cultural or service industries. Global integration has proceeded at the level of design and vehicle development as firms have sought to leverage engineering effort across products sold in multiple end markets. As suppliers have taken on a larger role in design, they in turn have established their own design centers close to those of their major customers to facilitate collaboration.

On the production side, the dominant trend is regional integration, a pattern that has been intensifying since the mid-1980s for both political and technical reasons. In North America, South America, Europe, Southern Africa and Asia, regional parts production tends to feed final assembly plants producing largely for regional markets. Political pressure for local production has driven automakers to set up final assembly plants in many of the major established market areas and in the largest emerging market countries, such as Brazil, India and China. Increasingly, lead firms demand that their largest suppliers have a global presence as a precondition to be considered for a new part. Because centrally designed vehicles are manufactured in multiple regions, buyersupplier relationships typically span multiple production regions.

Within regions, there is a gradual investment shift toward locations with lower operating costs: the U.S. South and Mexico in North America; Spain and Eastern Europe in Europe and South East Asia and China in Asia. Ironically, perhaps, it is primarily local firms that take advantage of such cost-cutting investments within regions (e.g. the investments of Ford, GM and Chrysler in Mexico), since the political pressure that drives inward investment is only relieved when jobs are created within the largest target markets (e.g. the investments of Toyota and Honda's in the US and Canada). Automotive parts, of course, are more heavily traded between regions than

4 Examples include right hand versus left hand drive, more rugged suspension and larger gas tanks for developing countries, and consumer preferences for pick-up trucks in Thailand, Australia and the United States.

5 The principal automotive design centers in the world are in Detroit, USA (GM, Ford and Chrysler, and more recently Toyota and Nissan); Cologne (Ford Europe), Rüsselsheim (Opel, GM's European division), Wolfsburg (Volkswagen) and Stuttgart (Daimler-Benz), Germany; Paris, France (Renault); and Tokyo (Nissan and Honda) and Nagoya (Toyota), Japan. 


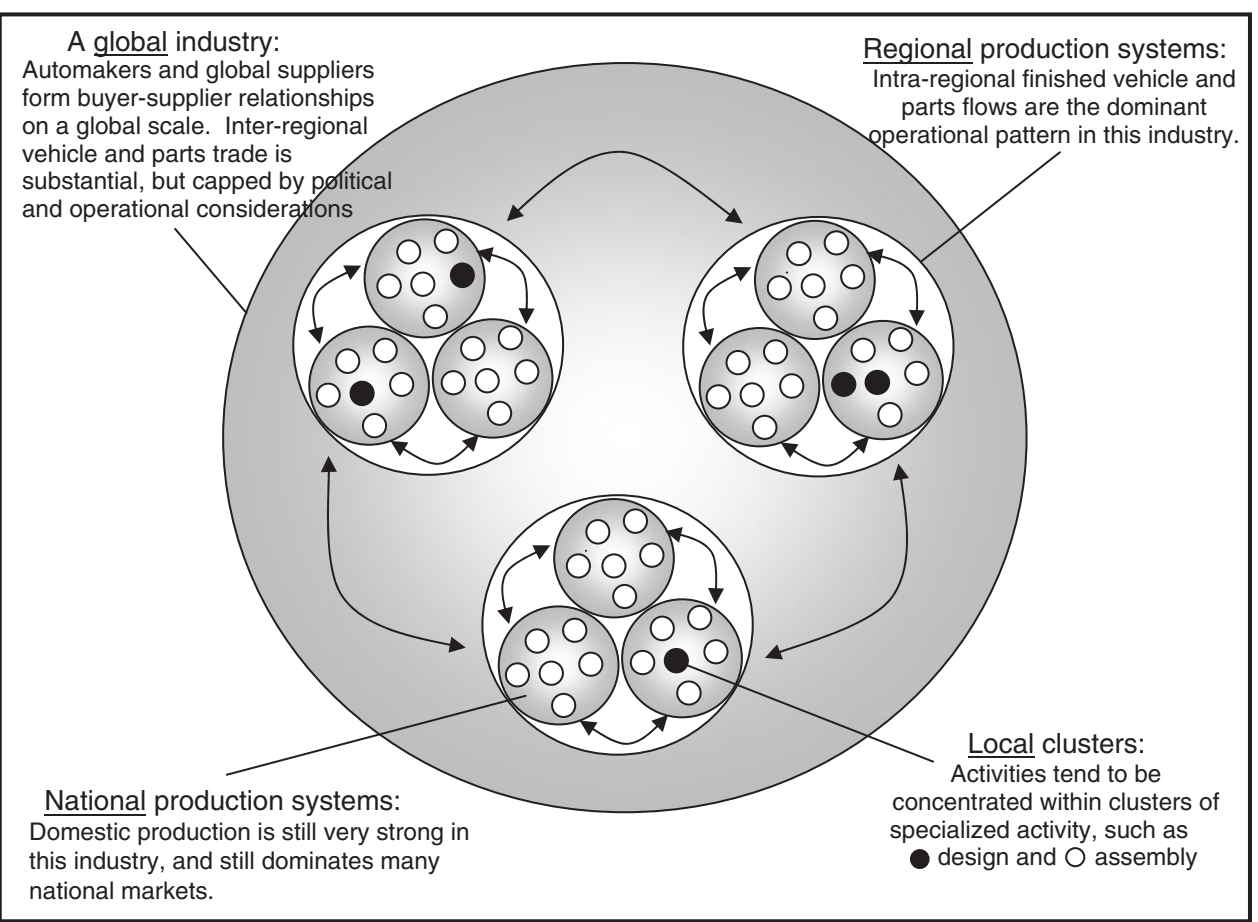

Figure 1. The nested geographic and organizational structure of the automotive industry.

finished vehicles. Within countries, automotive production and employment are typically clustered in one or a few industrial regions. In some cases, these clusters specialize in specific aspects of the business, such as vehicle design, final assembly or the manufacture of parts that share a common characteristic, such as electronic content or labor intensity. Because of deep investments in capital equipment and skills, regional automotive clusters tend to be very long-lived.

To sum up the complex economic geography of the automotive industry, we can say that global integration has proceeded the farthest at the level of buyer-supplier relationships, especially between automakers and their largest suppliers. Production tends to be organized regionally or nationally, with bulky, heavy, and model-specific parts production concentrated close to final assembly plants to assure timely delivery, and lighter, more generic parts produced at distance to take advantage of scale economies and low labor costs. Vehicle development is concentrated in a few design centers. As a result, local, national and regional value chains in the automotive industry are 'nested' within the global organizational structures and business relationships of the largest firms, as depicted in Figure 1. While clusters play a major role in the automotive industry, and have 'pipelines' that link them, there are also global and regional structures that need to be explained and theorized in a way that does not discount the power of localization.

\section{The outsourcing boom and rise of the global supplier}

One of the main drivers of global integration has been the consolidation and globalization of the supply base. In the past, multinational firms either exported parts 
to offshore affiliates or relied on local suppliers in each location, but today global suppliers have emerged in a range of industries, including motor vehicles (Sturgeon and Lester, 2004). Since the mid-1980s and through the 1990s, suppliers took on a much larger role in the industry, often making radical leaps in competence and spatial coverage through the acquisition of firms with complementary assets and geographies. This trend has been most pronounced among US-based suppliers. Figure 2, which traces the history of parts and assembly employment in the US from 1958 through 2002, clearly shows this structural shift. Until 1985, parts and assembly employment were roughly equal. After 1985, employment shifted into the supply base as automakers made fewer sub-assemblies such as cockpit assemblies, rolling chassis and seats in-house, purchasing them instead from outside suppliers. This drove rapid growth among the largest suppliers as well as consolidation, as firms engaged in mergers and acquisitions to gain the capability to make larger and more complex sub-systems. At the end of the 1990s, GM and Ford fully embraced the outsourcing trend by spinning off their respective internal parts divisions, creating what were at the time the world's two largest automotive parts suppliers, Delphi and Visteon. Because they were spun out of huge parent firms with strong international operations, these 'new' suppliers were born with a global footprint and the capability to supply complete automotive subsystems. ${ }^{6}$

A comprehensive overview of the largest suppliers in the automotive industry is regularly published by the main trade journal for the North American industry, Automotive News. Each year, a list is compiled of the top 150 parts suppliers in North America, the top 30 in Europe and the top 100 in the world. The addresses of headquarters, areas of specialization and sales are reported for each company. ${ }^{7}$ The changing composition of the list reveals the emergence of global suppliers. Figure 3 shows the rising importance, in terms of sales, of large suppliers relative to lead firms. ${ }^{8}$ In North America (the two grey lines at the bottom of Figure 3), vehicle production grew by $40 \%$ between 1991 and 2005, from 11.6 million to 16.3 million, while the combined sales of the largest 150 suppliers in North America nearly tripled. At the global level (the black lines at the top of Figure 3), vehicle production increased by $18.4 \%$ from 1999 to 2005, while supplier sales grew at more than twice that pace. Supplier consolidation at the worldwide level has not progressed as far as in North America, but it has picked up speed in recent years as the formation of new global lead firms and groups, such as DaimlerChrysler in 1999 (a deal that was undone in 2007), Nissan-Renault in 1998, Hyundai-Kia in 1999 and GM and Ford's purchase of several smaller companies, has led to the consolidation and integration of formerly distinct supply bases.

6 For example, according to company reports, Visteon has broad capabilities in chassis, climate, electronics, glass and lighting, interior, exterior trim and power trains. In 2000, the company operated 38 manufacturing plants in the US and Canada; 23 in West Europe; 21 in Asia; nine in Mexico; six in East Europe and four in South America. System and module engineering work was carried out in one facility in Japan, three in Germany, three in England, and four in the US.

7 The list for North America was first published in 1992 and with the exception of 1994 it has appeared each year since. The European and worldwide lists have been published since 1999 .

8 The only output measure we observe for firms on the list is nominal sales, but it is useful to keep in mind that the price per vehicle (controlling for quality) has remained almost flat over the last 15 years. The CPI index for new vehicles in the US saw a cumulative increase from 1992 to 2005 of $4.3 \%$; between 1997 and 2005 it even recorded a decline of $5.5 \%$. 


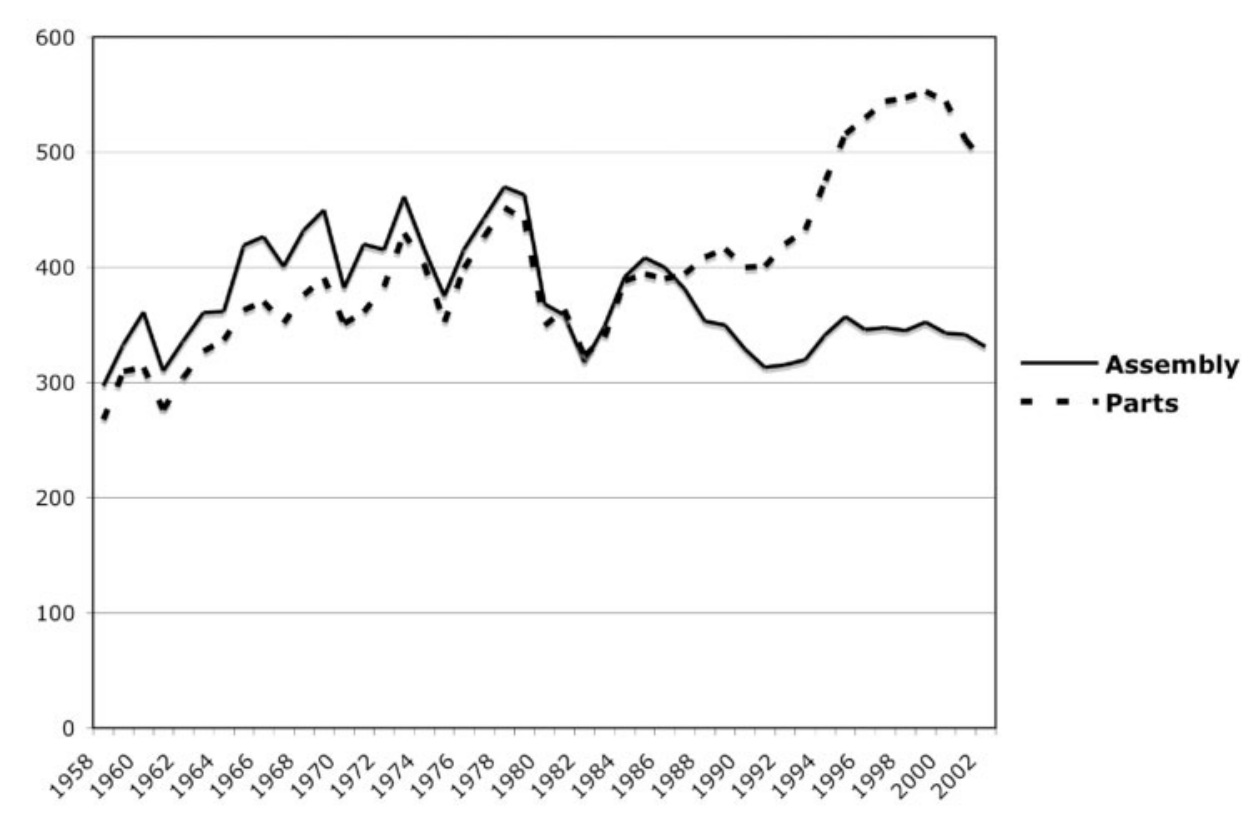

Notes: Assembly includes SIC 3711 (Motor Vehicles and Car Bodies) and Parts includes SIC 3714 (Motor Vehicle Parts and Accessories). SIC basis data is unavailable after 2002.

Source: Employment, Hours, and Earnings from the Current Employment Statistics Survey, SIC basis (U.S. Bureau of Labor Statistics).

Figure 2. Outsourcing in the U.S. automotive industry, assembly and parts employment, $1958-2002$.

As automakers set up final assembly plants in new locations and tried to leverage common platforms over multiple products and in multiple markets, they pressured their existing suppliers to move abroad with them. Increasingly, the ability to produce in all major production regions has become a precondition to be considered for a project. However, what is emerging in the automotive industry is more complex than a seamless and unified global supply base, given the competing pressures of centralized sourcing (for cost reduction and scale) and regional production (for just-in-time and local content). The need for full co-location of parts with final assembly varies by type of component, or even in stages of production for a single complex component or subsystem. Suppliers with a global presence can concentrate volume production of specific components in one or two locations and ship them to plants close to their customer's final assembly plants where modules and sub-systems are built up and sent to nearby final assembly plants as needed.

What should be clear from this discussion is that the economic geography of the automotive industry cannot be reduced to a simple network of clusters. Business relationships now span the globe at several levels of the value chain. Automakers and first tier suppliers have certainly forged such relationships, and as the fewer, larger suppliers that have survived have come to serve a wider range of customers, these relationships have become very diverse. With consolidation, we must question the 


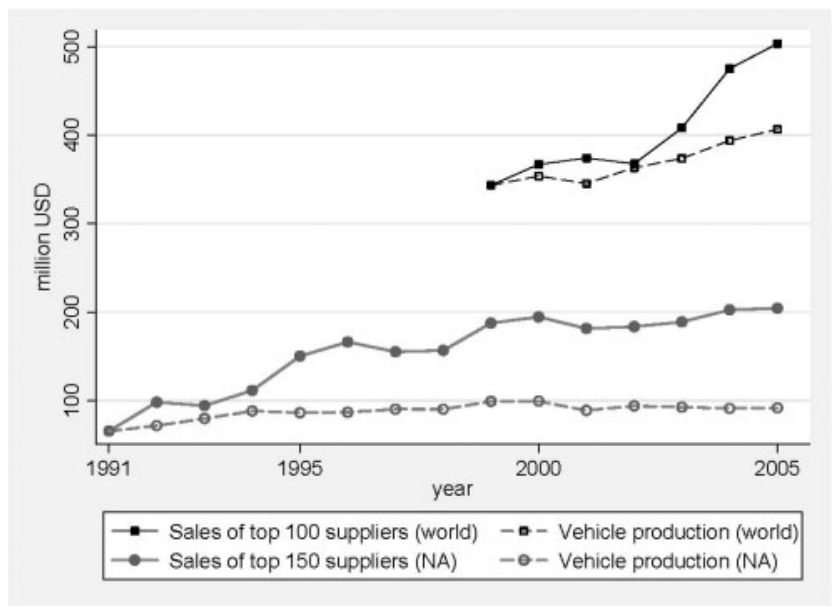

Source: Information for the top suppliers is taken from Automotive News (various years). Information on vehicle production is from Ward's Automotive Yearbook (2006).

Notes: The scale is for the sales numbers in millions of current U.S. dollars.

The vehicle production series has been scaled to coincide with the relevant sales

number in the initial year.

Figure 3. The increasing importance of suppliers in the automotive industry.

staying power of smaller, lower tier, local suppliers, however well supported they are by local institutions and inter-firm networks, especially since many upstream materials suppliers, such as the automotive paint supplier PPG, are huge companies that have set up global operations as well.

\section{GVC governance in the automotive industry: dealing with the 'problem' of relational linkages}

GVC theory identifies five ways that firms coordinate, or govern the linkages between value chain activities: (i) simple market linkages, governed by price; (ii) modular linkages, where complex information regarding the transaction is codified and often digitized before being passed to highly competent suppliers; (iii) relational linkages, where tacit information is exchanged between buyers and highly competent suppliers; (iv) captive linkages, where less competent suppliers are provided with detailed instructions and (v) linkages within the same firm, governed by management hierarchy. These five linkage patterns can be associated with predictable combinations of three distinct variables: the complexity of information to be exchanged between value chain tasks; the codifiability of that information; and the capabilities resident in the supply base (Gereffi et al., 2005).

In the automotive industry, a paucity of robust, industry-wide standards and codification schemes limits the rise of true value chain modularity. Why are there so few open standards and industry-level codification schemes in the automotive industry? We see two main reasons, the first technical and the second structural. On the technical side, vehicle performance characteristics such as noise, vibration and handling are deeply interrelated and it is difficult to quantify their interactions in advance (Whitney, 1996). 
Because of the integral nature of vehicle design architecture, changes in one component often have an impact on other components (Novak and Wernerfelt, 2006). Rising vehicle complexity has continued to overwhelm efforts to fully codify vehicle designs or the design process. The industry has historically relied on inter-personal interaction and proprietary standards, mostly within the boundaries of vertically integrated firms, to manage the flow of tacit information from one stage of the chain to the next. As a result, information exchange between suppliers of complex parts and sub-systems and lead firms is necessarily very intensive. Suppliers are often the sole source for a myriad of vehicle- and platform-specific parts, which raises the costs of serving multiple customers. On the structural side, the extremely concentrated structure of the industry gives a small number of lead firms an extraordinary amount of power over suppliers. In GVC parlance, value chains in the automotive industry are strongly 'driven' by a small number (around 11) of producers (Gereffi, 1994). Their huge purchasing power means that each lead firm can force suppliers to accommodate its idiosyncratic standards, information systems and business processes.

Because the largest suppliers in the industry have also undergone a massive wave of consolidation of their own, they have taken on much larger roles in the areas of design, production, and foreign investment. As the competence to design complex parts and sub-systems has shifted from automakers to suppliers, the need for co-design has meant that captive and pure market GVC linkages have become harder to maintain. At the same time, the lack of open, industry-level standards for vehicle parts and sub-systems (low codifiability) has blocked the development of industry-wide codification schemes needed to support modular GVC linkages, heightened the need for close collaboration, tied suppliers more tightly to lead firms, and limited economies of scale in production and economies of scope in design. ${ }^{9}$ As a result, linkages between lead firms and suppliers in the automotive industry require tight coordination, especially in the areas of design, production and logistics (Humphrey, 2003).

American and Japanese lead firms have tended to respond differently to this pressure to forge deep relational linkages, based in large part on their historical ties to suppliers. American lead firms have tended to develop market linkages and have used the ability to switch suppliers to engage in predatory purchasing practices (Helper, 1991). As the acceleration of outsourcing in the 1990s bundled more value chain functions in supplier firms, supplier relations did not change. American automakers tend to systematically break relational ties after the necessary collaborative engineering work has been accomplished. The result is an oscillation between relational GVC linkages, driven by the engineering requirements of vehicle development in the context of increased outsourcing, and market linkages, which are adopted once lead firms put co-developed parts, modules and sub-systems out for open re-bid after a year or so of production in an effort to lower input costs. Switching the sourcing of a part, or a sub-system consisting of many parts, from a supplier that engaged in co-design to a supplier that did not is only possible once the specifications have been fully developed and stabilized in the context of high volume production. Reversion to market linkages may keep

9 Lead firms have been trying to decrease the design effort required for vehicle development by sharing vehicle platforms across a family of vehicle models, but this has its limits. First, platforms are only shared across brands owned by the same lead firm. Second, to avoid product homogenization and to achieve performance goals, most parts that are visible to consumers and many that are not, remain model-specific. 
supplier power in check, but it wreaks havoc on the accumulated trust needed for relational linkages function effectively (Granovetter, 1985; Adler, 2001).

As Herrigel (2004) has shown, this has created deep tensions in the automotive components industry. Especially relevant here is the fact that suppliers are often expected to recover the cost of design services as part of winning the initial contract. For suppliers, the costs of these purchasing practices are extremely high. In fact, high design costs, which are often only partially compensated because of predatory purchasing practices and the declining sales volumes of the Big 2, combined with unexpected rises in the price of raw materials, also uncompensated by the Big 2, are major factors behind a recent spate of bankruptcies among large automotive suppliers based in the US (Figure 4).

It is notable that no Japanese suppliers appear in Figure 4. In post-World War II Japan, lead firms were starved for capital and needed to rely more on suppliers. This often involved equity ties and suppliers dedicating themselves to serving their largest customer, in a classic 'captive' relationship that became more relational over time as supplier competence increased. Relative to what American automakers have recently and quite suddenly asked their suppliers to contribute, Japanese lead firms have limited co-design with suppliers. Predatory supplier switching is almost unheard of, and longterm trust-based relationships have been allowed to develop. Paternalistic 'captive' linkages to suppliers have been partly maintained, especially when these relationships have been projected outside of Japan. While Japanese automakers have a higher level of acceptance of relational GVC linkages than American automakers, Japanese automakers have asked less of their suppliers in the realm of co-design, and this has provided an alternative mechanism to attenuate supplier power.

The adversarial relationships between American lead firms and their suppliers shows up clearly in Table 1, which presents an annual 'working relations index' calculated by the consultancy Planning Perspectives. Japanese automakers rely on many locally based suppliers in North America, and have achieved much better working relationships with them than the American Big 3. In 2007, 52\% of North American suppliers participated in the survey. They clearly rate their relationships with Japanese lead firms as better than their relationships with American automakers. Chrysler tended to have better relationships with suppliers than its American competitors, but recent financial difficulties have driven the company to predatory buying practices. While 'bad' working relationships are to some extent symptomatic of declining sales volumes, which leads American automakers to overestimate future sales and makes it harder for suppliers to recover fixed costs, Japanese lead firms clearly have brought their customary relational approach to buyer-supplier linkages with them as they have located production in North America.

In short, place-based institutions are being projected outward as global integration unfolds. The case of the automotive industry reveals the complexity of social and institutional embeddedness as the largest firms have established global operations. When firms set up operations in new places, they rarely abandon their home bases completely, but remain rooted there in significant ways. Most typically, this involves command and control functions, the development and deployment of corporate strategy, and the functions of product conception and design. Even manufacturing plants are commonly left in operation, both to serve the home market and to supplement offshore production through exports. In this way, the institutions of localities and countries continue to influence the behavior of firms at home as well as in 


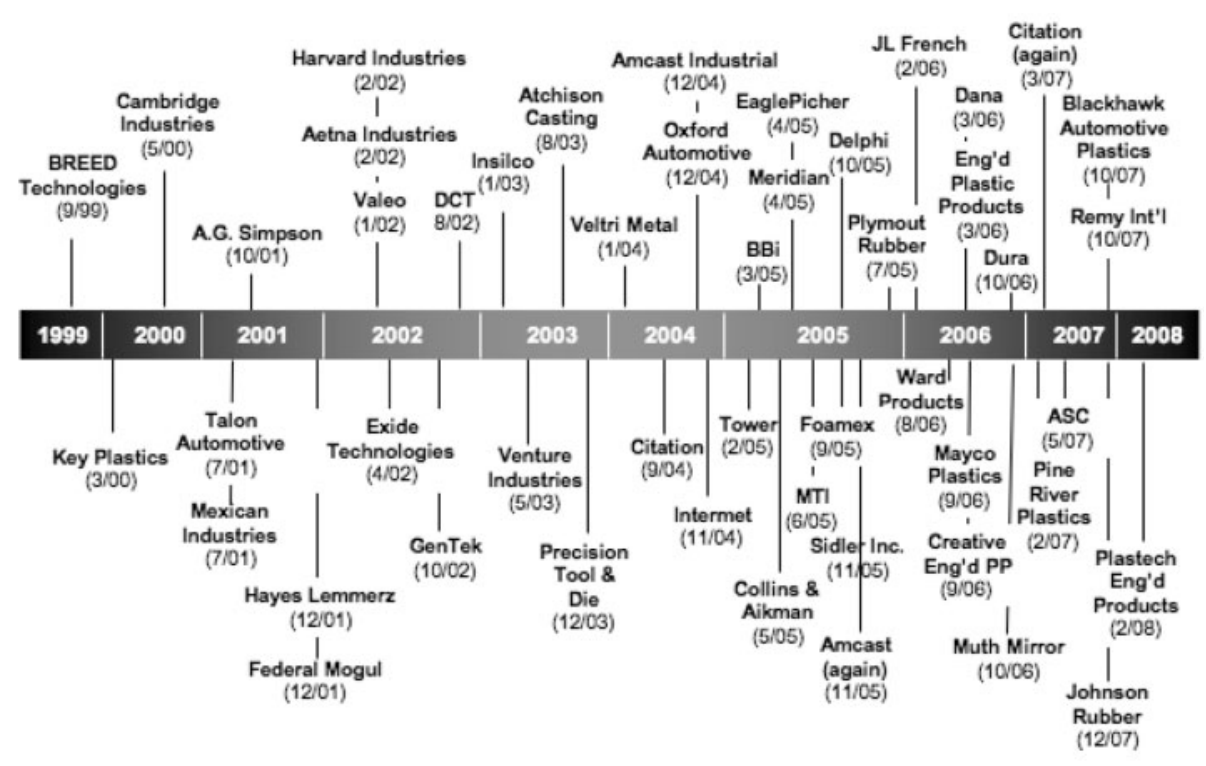

Source: Korth (2006/2008), IRN Inc.

Figure 4. Major Automotive Supplier Bankruptcies, 1 January 1999 to 10 February 2008.

the new institutional environments they find offshore (Berger and the MIT Industrial Performance Center, 2005). Thus, it is not surprising that we find Japanese automakers behaving like Japanese firms in North America. On the other hand, globalization is more than the simple offshore projection of national 'varieties of capitalism' (Hall and Soskice, 2001). Firms adapt to, and in some cases actively embrace, different institutional environments when they move offshore, especially when home institutions have been perceived as constraints on management action. ${ }^{10}$

\section{Explaining the strength of regional production in the automotive industry}

Since the late 1980s, trade and foreign direct investment have accelerated dramatically in many industries. Specifically, a combination of real and potential market growth with a huge surplus of low-cost, adequately skilled labor in the largest countries in the developing world, such as China, India and Brazil, has attracted waves of investment, both to supply burgeoning local markets and for export back to developed economies. The latter has been enabled and encouraged by the liberalization of trade and investment rules under an ascendant World Trade Organization (WTO). Yet, regional production has remained very durable in the automotive industry. As we argued

10 For example, GM and Volkswagen have both used their plants in Brazil and Eastern Europe to experiment with new production models, work organization practices and supplier relations (Sturgeon and Florida, 2004). 
Table 1. Index of working relations between lead firms and suppliers

\begin{tabular}{lccccccc}
\hline & 2002 & 2003 & 2004 & 2005 & 2006 & 2007 & 2002-07 Change (\%) \\
& & & & & & & 32.2 \\
Toyota & 0.76 & 0.80 & 0.99 & 1.00 & 0.98 & 1.00 & 27.9 \\
Honda & 0.72 & 0.76 & 0.93 & 0.90 & 0.89 & 0.92 & 27.3 \\
Nissan & 0.55 & 0.62 & 0.73 & 0.72 & 0.72 & 0.70 & 13.7 \\
Chrysler & 0.42 & 0.43 & 0.45 & 0.47 & 0.53 & 0.48 & 8.1 \\
Ford & 0.40 & 0.39 & 0.39 & 0.38 & 0.42 & 0.39 & 0.42 \\
GM & 0.39 & 0.38 & 0.36 & 0.27 & 0.32 & 0.4 \\
Industry Mean & 0.54 & 0.56 & 0.64 & 0.62 & 0.64 & 0.65 & 20.7 \\
\hline
\end{tabular}

Note: The Working Relations Index (WRI) ranks OEMs' supplier working relations based on 17 criteria across five (5) areas: OEM-Supplier Relationship, OEM Communication, OEM Help, OEM Hindrance and Supplier Profit Opportunity. A score below 0.60 is considered to represent very poor to poor supplier working relations; a score between $0.60-0.84$ indicates adequate relations and above 0.84 indicates good to very good supplier working relations.

Source: Planning Perspectives, Inc. web site (4 June 2007, press release) http://www.ppil.com/news/?image=news

previously, lead firms in the automotive industry have the power to drive supplier co-location at the regional, national, and local levels for operational reasons, such as just-in-time production, design collaboration, and the support of globally produced vehicle platforms. But politics also motivates lead firms to locate production close to end markets, and this also creates pressure for supplier co-location.

While consumer tastes and purchasing power, driving conditions, and the nature of personal transportation can vary widely by country, local idiosyncrasies in markets and distribution systems are common in many industries, and it is possible to feed fragmented and variegated distribution systems from centralized production platforms, as long as product variations are relatively superficial. The continued strength of regional production in the automotive industry, then, is one of its most striking features (Lung et al., 2004). ${ }^{11}$ The regional organization of vehicle production stands in stark contrast to other important high-volume, consumer-oriented manufacturing industries, especially apparel and electronics, which have developed global-scale patterns of integration that concentrate production for world markets in a few locations.

Why is political pressure for local production felt so acutely in the automotive industry? The high cost and visibility of automotive products, especially passenger vehicles, among the general population can create risks of a political backlash if imported vehicles become too large a share of total vehicles sold. This situation is heightened when local lead firms are threatened by imports. The case of Japanese exports to the US in instructive. In the 1960s and 1970s, Japanese (and to a lesser extent European) automakers began to gain substantial market share in the US market through exports. Motor vehicle production in Japan soared from a negligible 300000 units in 1960 to nearly eleven million units in 1982, growing on the strength of Japan's largely protected domestic market of about five million units plus exports (Dassbach, 1989). Excluding intra-European trade, Japan came to dominate world

11 Of the three major vehicle-producing regions, regional integration is the most pronounced in North America. In $2004,75.1 \%$ of automotive industry trade was intra-regional there, in contrast to $71.2 \%$ in Western Europe, and 23\% in Asia (Dicken, 2007, 305). 
finished vehicle exports by a wide margin, with the bulk of exports going to the $\mathrm{U} S$ (Dicken, 2007).

The remarkable success of Japanese automakers' export strategy resulted in a gain in market share in the US that came at the direct expense of the American Big 3, sparking a political backlash that resulted in the setting of 'voluntary' limits to market-share expansion via exports. A stark reality added fuel to the fire: American automakers had been, and continue to be, unable to penetrate Japan's domestic market in any meaningful way. In response to these so-called voluntary quotas, Japanese automakers embarked on a wave of plant construction in the US during the 1980s, and by 1995 were locally manufacturing two-thirds of the passenger vehicles they sold in the US (Sturgeon and Florida, 2004). ${ }^{12}$

As Japanese 'transplant' production in North America ramped up after 1986, Japanese exports began a long decline. Table 2 lists existing and planned assembly plant investments in North America by "foreign" firms. By 2009, transplants in North America will have the capacity to assemble more than six million units, more than one-third of projected U.S. demand in 2011, and will employ $~ 90000$ workers, just under one-third of North American assembly employment in 2005 (Sturgeon et al., 2007).

Figure 5 shows how U.S. vehicle demand has been satisfied by a combination of overseas imports, regional imports from Mexico and Canada, and domestic production during the period 1972-2006 (with 2007-2011 forecast). After an initial build up of imports from countries outside of NAFTA over the 1972-1982 period, especially Japan, overseas vehicle imports declined dramatically as Japanese and subsequently European lead firms established final assembly operations in North America. Since then, overseas imports have increased as demand, mainly for Japanese vehicles, outstripped installed capacity in North America. The announced North American assembly plants planned by Japanese and Korean firms will largely offset the increase in overseas imports between 1995 and 2006. As a result, we expect that imports from these countries will again decline, as projected by JD Power. Because of the high cost, large scale, and long life of assembly plant investments, this cyclical variation in finished vehicle imports (and assembly plant investments) can be expected in the future if market share continues to shift in favor of non-US-based firms. Plants will only be added if and when these firms are confident that market share gains in North America will be long standing.

This pattern reveals the sensitivity to high levels of imports, especially of finished vehicles, in places where local lead firms are present, as they are the US. In our view, the willingness of governments to prop up or otherwise protect local automotive firms is comparable to industries such as agriculture, energy, steel, utilities, military equipment and commercial aircraft. As a result, lead firms in these industries have to adjust their sourcing and production strategies to include a measure of local and regional production that firms in other industries do not. This explains why Japanese, German and Korean automakers in North America have not concentrated their production in Mexico, despite lower operating costs and a free trade agreement with the US

12 Around the same time, starting with Nissan in 1986 in the UK, Japanese firms constructed assembly plants in Europe to avoid import quotas in France and Italy and import tariffs in most other E.U. countries. 
Table 2. Existing and announced foreign assembly plant investment in North America

\begin{tabular}{|c|c|c|c|c|c|}
\hline Company & Location & $\begin{array}{c}\text { Employment } \\
\text { (as of } 2004 \text { or } \\
\text { planned) }\end{array}$ & $\begin{array}{c}\text { Investment } \\
\text { (\$M, through } 2005 \\
\text { or planned) }\end{array}$ & $\begin{array}{l}\text { Capacity } \\
\text { (2005 or } \\
\text { planned) }\end{array}$ & $\begin{array}{l}\text { Opening date } \\
\text { (first major } \\
\text { expansion) }\end{array}$ \\
\hline Kia & Troup County, GA & 2500 & 1200 & 300,000 & 2009 \\
\hline Honda & Greensburg, IN & 2000 & 550 & 200,000 & 2008 \\
\hline Toyota & Woodstock, ON & 2000 & 950 & 150,000 & 2008 \\
\hline Toyota & San Antonio, TX & 2000 & 850 & 200,000 & 2006 \\
\hline Hyundai & Hope Hull, AL & 2000 & 1100 & 300,000 & 2005 \\
\hline Toyota & Tecate, MX & 460 & 140 & 50,000 & 2005 \\
\hline Nissan & Canton, MS & 4100 & 1430 & 400,000 & 2003 \\
\hline Honda & Lincoln, AL & 4300 & 1200 & 300,000 & 2001 \\
\hline Volkswagen & Puebla, MX & 15,000 & NA & 380,000 & 1966 (1998) \\
\hline Daimler-Benz & Vance, AL & 4000 & 2200 & 160,000 & 1997 \\
\hline Toyota & Princeton, IN & 4659 & 2600 & 300,000 & 1996 \\
\hline BMW & Spartenburg, SC & 4600 & 2200 & 200,000 & 1994 \\
\hline GM/Suzuki & Ingersoll, ON & 2775 & 500 & 250,000 & 1989 \\
\hline Honda & East Liberty, $\mathrm{OH}$ & 2230 & 920 & 240,000 & 1989 \\
\hline Subaru & Lafayette, IN & 1315 & 1350 & 262,000 & 1989 \\
\hline Toyota & Georgetown, KY & 6934 & 5310 & 500,000 & 1988 \\
\hline Mitsubishi & Normal, IL & 1900 & 850 & 240,000 & 1988 \\
\hline Toyota & Cambridge, ON & 4342 & 2400 & 250,000 & 1988 \\
\hline Honda & Alliston, $\mathrm{ON}$ & 4375 & 1500 & 250,000 & 1987 \\
\hline GM/Toyota & Fremont, CA & 5715 & 1300 & 370,000 & 1984 \\
\hline Nissan & Smyrna, TN & 6700 & 1600 & 550,000 & 1983 \\
\hline Honda & Marysville, $\mathrm{OH}$ & 4315 & 3200 & 440,000 & 1982 \\
\hline Nissan & Aguascalientes, Mx & NA & NA & 200,000 & 1966 (1982) \\
\hline Total & & $88,220^{*}$ & $33,350^{* *}$ & $6,292,000$ & \\
\hline
\end{tabular}

Notes: NA = data not available. Dates in brackets indicate major capacity expansions.

Sources: Compiled from Automotive News, Ward's Automotive, McAlinden (2006) and company websites.

*Missing employment from Nissan, Aguascalientes.

*** Missing investment in Volkswagen, Puebla, Nissan, Aguascalientes, and GM, Spring Hill plants.

(Sturgeon et al., 2007). ${ }^{13}$ Japanese automakers have also shifted European production to Eastern Europe later and less aggressively than American and European lead firms, and have even moved to China later than their European and American competitors. ${ }^{14}$

Despite the rise of a more integrated global supply base, described earlier, the continued strength of regional structures in the automotive industry is still reflected in the relationship between supplier headquarters and regional sales. As recently as 1999, almost half of the 100 largest suppliers were based in North America, as this was the largest regional market. At the same time, regional sales were $70 \%$ of total sales for suppliers based in North America, and 65\% for suppliers based in Europe and Japan.

13 Volkswagen is exceptional in that it has concentrated all of its North American production in Mexico, and Nissan is the sole Japanese automaker that has build up large scale, export-oriented final assembly there.

14 The large U.S. trade deficit with China might have influenced Honda's decision to export the Honda Jazz to the European Union from China, while the almost identical Honda Fit for North America is shipped from Japan. 


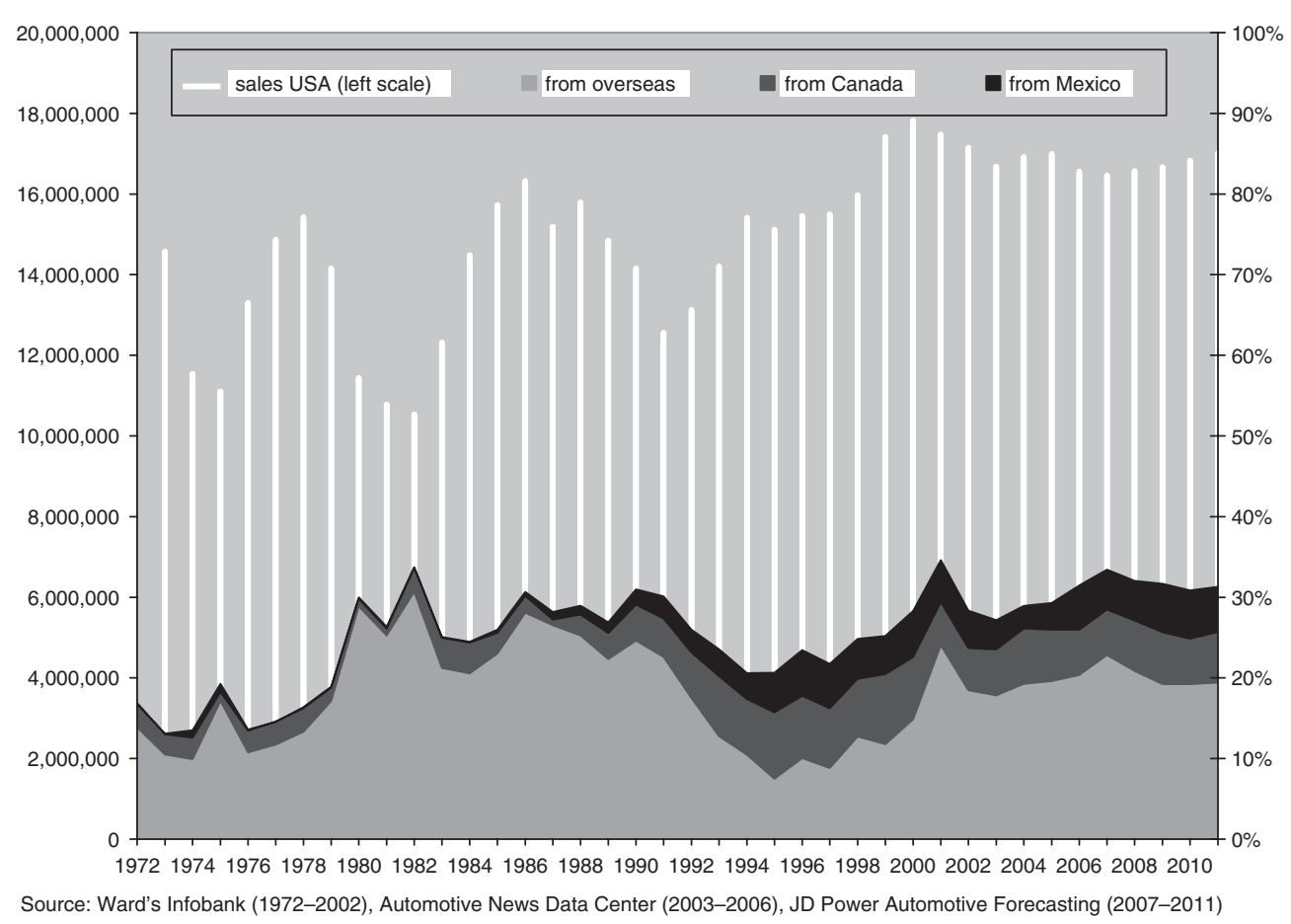

Figure 5. Net vehicle imports in the US from Mexico, Canada and countries outside of North America, 1972-2011 (forecast).

However, Figure 6 illustrates that this situation changed in the following years, as global sourcing by lead firms increased extra-regional sales by Tier 1 suppliers. First, global sourcing has caused the list of top suppliers to become more regionally balanced. The number of top suppliers coming from each of the three regions, in the left panel, now reflects the worldwide production share of the lead firms of the respective regions. Second, by 2005 average sales in home regions declined from $68.6 \%$ to $61.6 \%$ for the 100 largest suppliers, which are shown broken down by region in the right panel. The decline has been particularly pronounced for North American-based suppliers. Asian headquartered suppliers' increased extra-regional sales modestly and European suppliers' extra-regional sales remained flat during the same period. Nevertheless, examples abound of suppliers from Germany and Japan following their largest customers offshore as extra-regional final assembly has grown. ${ }^{15}$

15 An example of a small Japanese firm that has set up a global operational footprint is F-Tech, a Honda supplier headquartered in Saitama Prefecture, north of Tokyo. The company produces engine and rear suspension parts, engine supports, rear axles, pedal and clutch assemblies and bumper beams. The company began supplying Honda in 1956, and in 1967 established the first of several plants in Kameyama, a few minutes away from Honda's assembly complex in Suzuka. Honda and F-Tech engage in a classic 'captive' relationship. Honda provides close guidance in terms of planning, purchasing and production methods, and accounts for most of F-Tech's output, especially for offshore plants, which are 

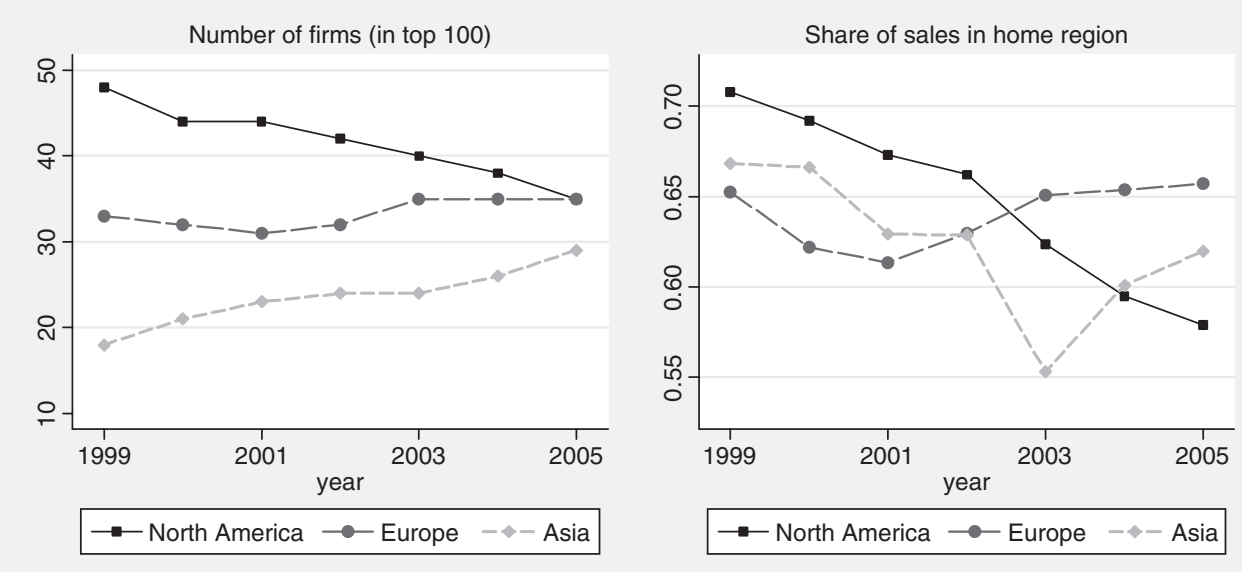

Source: Automotive News top supplier list (various years)

Figure 6. Regional organization of the automotive supply base.

\section{The persistence of Motor City: the greater Detroit vehicle development cluster}

At the same time that lead firm consolidation and dispersal is being reflected in the consolidation and dispersion of the supply-base, the increased involvement of suppliers in design and purchasing has led to the spatial concentration of supplier design engineering facilities, especially in North America, where lead firms have been the most aggressive in demanding that suppliers contribute to design efforts. Because the Detroit, Michigan area has been a center of vehicle design and engineering for nearly 100 years, the cluster boasts specialized labor markets and a host of institutions to support the field of automotive engineering. As a result, the regional headquarters of foreign automakers and global suppliers-typically the site of regional sales, program management, design and engineering - have gravitated to the Detroit area.

Even though Japanese automakers have built many assembly plants in the U.S. South, their design and R\&D activities tend to be among the most northerly points of their U.S. operations. In 2005, Toyota consolidated much of its design and R\&D activities in Ann Arbor, Michigan (a 45 min drive from Detroit), even though its North American manufacturing headquarters are located in Kentucky. In 2006, Nissan moved

typically $100 \%$ dedicated to Honda. Over time, F-tech has broadened its customer base in Japan beyond its lead customer; the company began serving Nissan in 1995, Isuzu in 1997, Daihatsu in 1999 and Suzuki in 2001. Outside Japan, however, F-tech's plants remain tightly linked to Honda's offshore assembly plants. In 1986, F-Tech followed Honda offshore, establishing the subsidiary F \& P Mfg., Inc. in Tottenham, Ontario, a few miles from Honda's Alliston assembly plant, which opened the same year. In 1993, the company opened F\&P America in Troy, Ohio, less than an hour's drive from Honda's East Liberty assembly complex. A technical center and North American headquarters followed in 2001. In addition to these closely linked facilities, F-tech has several high-volume plants in low cost locations that are not tied to any one assembly plant, including a plant in Laguna State, the Philippines, established in 1996; a plant in Wuhan, China, near Shanghai, established in 2004; and a plant in Ayutthaya, Thailand, opened in 2006. 


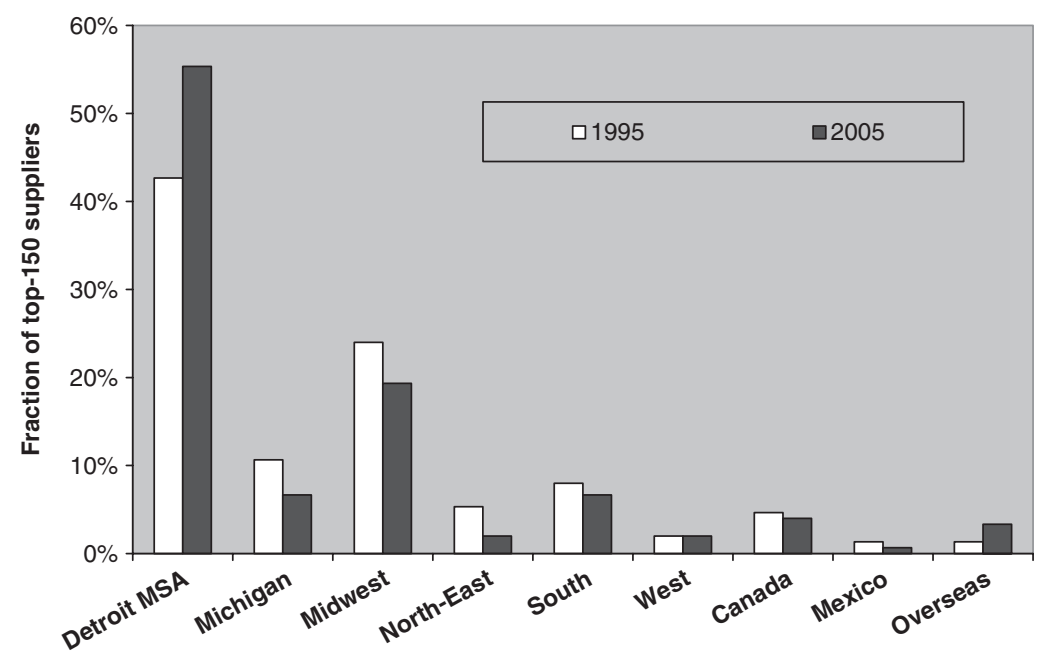

Source: Author calculations based on Automotive News top 150 ranking (various years).

Figure 7. Location of (regional) headquarters of top 150 suppliers to the North American automotive industry.

its North American headquarters from Los Angeles, California to the Nashville, Tennessee area. Nissan's conceptual design center is in San Diego, California, but the 8 -fold larger engineering-oriented technology center is in Farmington Hills, a Detroit suburb. Honda's North American automotive R\&D operations are split between California, near Los Angeles, responsible for market research, concept development and vehicle styling, and Raymond, Ohio (about 150 miles south of Detroit), responsible for complete vehicle development, testing and the support of supplier and manufacturing operations.

As the global consolidation of the supply base has proceeded, suppliers based in Europe and Asia, such as Yazaki (Japan), Bosch (Germany), Autoliv (Sweden) and many others, have established major design centers in the Detroit region to support their interactions with American, and increasingly, Japanese automakers. The headquarters location of the largest 150 suppliers in the region, which includes regional headquarters for some transnational firms, is documented in Figure 7. The importance of Detroit is striking: by 2005, the majority of the largest suppliers were located in the Detroit Metropolitan Region. This fraction increased from $43 \%$ in 1995 to $55 \%$ in 2005. The concentration is even more striking for the 50 largest suppliers: by 2005, 34 of those were located in the Detroit area, up from 29 in 1995. As regional headquarters have multiplied in Detroit, the number has fallen in the rest of Michigan and other Midwestern states, and has dropped to near zero in the Northeast. Even the U.S. South, which has attracted many new assembly plants in the last decade, has lost supplier headquarters.

As the largest suppliers locate engineering work near lead firm design facilities, it places pressure on smaller suppliers to locate engineering work close to their biggest clients. This is a classic agglomeration dynamic that is strengthening the Detroit automotive design cluster, even as final assembly is gradually shifting away from the 
area. As Bathelt et al. (2004) point out, co-location is by no means an absolute requirement for transfer of tacit knowledge, nor is it sufficient. In the automotive case, however, co-location has a strong temporal component. Vehicle programs take shape over several months or even years, and any lead firm has dozens of programs in the pipeline at any point in time. Getting involved in these projects would be extremely difficult for suppliers without a presence in the cluster. Thus in terms of the development, maintenance, and exchange of tacit knowledge in the automotive industry, the assumptions of the clusters literature ring true.

\section{Conclusions}

In this article, we have used the three main elements of the GVC approach-power, institutions and inter-firm governance-to help to explain some of the distinctive characteristics of the global automotive industry. One of our goals has been to highlight several features that set the automotive industry apart from other global goodsproducing industries, such as electronics and apparel. First, the automotive industry is similar to these others in that the geographic scope of both lead firms and their largest suppliers expanded in a wave of offshore investments, mergers, acquisitions and equitybased alliances in the 1990s. In industry after industry, giant firms have arisen in many vertical segments of the value chain, and these firms are building relationships with one another at the global level (Sturgeon and Lester, 2004).

Second, the automotive industry, especially firms based in the US, embraced outsourcing without a robust set of industry standards in place for specifying the technical characteristics of products and processes. To some extent, this reflects the difficulty of codifying tacit knowledge about mechanical processes but it also reflects the strong competition between a tight oligopoly of very powerful lead firms unwilling to work together to develop robust industry-level standards. Because parts and subsystems tend to be specific to vehicle platforms and models, suppliers have been forced to interact closely with lead firms, which has driven up transaction costs, and limited the economies of scale in production and economies of scope in design afforded by value chain modularity. The different approaches that lead firms have taken toward solving such GVC governance challenges have helped to shape competitive outcomes, for lead firms and for the supply base as a whole.

Third, in the automotive industry, technical necessity, political sensitivities and market variation have kept final vehicle assembly, and by extension much of parts production, close to end markets. Powerful lead firms and industry associations, largescale employment and relatively high rates of unionization, and the iconic status of motor vehicles in the minds of consumers (and policy-makers) in many countries increase the political clout of the automotive industry. So even where import tariffs and local content rules are not present or are scheduled to decline under WTO rules, foreign assemblers have chosen to 'voluntarily' restrict exports and set up local production to forestall political backlash. As a result, regional and national production structures remain surprisingly strong and coherent in comparison to other volume good producing industries where global sourcing of parts and materials is the norm and worldwide demand for finished goods can be met from a handful of giant production clusters. As a result, political pressures go a long way toward explaining patterns of direct investment in the automotive industry. 
Fourth, the economic geography of the automotive industry is playing out differently in different segments of the value chain. We see the concentration of design engineering in existing clusters, dispersal of some conceptual design to gain access to 'lead users', regional integration of production, and for some categories of parts, global sourcing. In all instances, however, it is automakers that drive locational patterns; the influence that lead firms have on the economic geography of the industry is rooted in their enormous buying power.

The automotive industry is clustered and dispersed, rooted and footloose. The industry can be usefully conceived of as a network of clusters, but our conceptual and methodological tools should not blind us to the importance and durability of structures that function at the level of continental-scale regions. A theory of economic geography must be fully scalable to accommodate and account for these variations. It must seek to accommodate and offer explanation for what appear to be contradictory tendencies in the spatial organization of capitalism without setting up false contests, for example, between the relative importance of clustering and dispersal. The value chain perspective, first and foremost, draws our attention to the division of labor in an industry, especially its vertical dimension, for the simple reason that various business functions along the chain have different requirements, and these requirements help to structure the geography of the chain, and by extension, global industries.

As Ann Markusen (2003) points out, we should be wary of 'fuzzy concepts' that are difficult to operationalize, measure, or feed into policy. It is fair to ask if concepts such as global value chains and global production networks suffer from such drawbacks. In our view, the simplicity of the chain metaphor increases its usefulness as a research methodology and policy input. While we recognize the inherent limits of the GVC framework, scalable conceptual tools that can help researchers and policymakers move easily from local to global levels of analysis demand some degree of parsimony. As global integration continues to drive the complexity of the analytical problem upward, the need for such guideposts will only grow. While debates over the relative merits of terms and metaphors, such as commodity chains, value chains, production networks, and the meaning of terms such as 'value' and 'governance' will certainly continue, what this signifies is the emergence of a coherent interdisciplinary intellectual community with a shared focus on the organizational and spatial dynamics of industries, the strategies and behavior of major firms and their suppliers, and the structuring roles of institutions, power, and place. These commonalities, in our view, define a core research and theory building agenda that cuts across these chain and network paradigms. As we have pointed out elsewhere (Sturgeon, forthcoming), this theoretical project is at an early stage of development.

\section{References}

Adler, P. (2001) Market, hierarchy, and trust: the knowledge economy and the future of capitalism. Organization Science, 12(2): 215-234.

Automotive News Market Data Books, various years. Available online at: http://www.autonews. com/section/DATACENTER, Automotive News Data Center (accessed 13 March 2008).

Automotive News. (Various years) Top 150 North American Suppliers. http://www.autonews. com, Automotive News Data Center, accessed March 13, 2008.

Bathelt, H., Malmberg, A., Maskell, P. (2004) Clusters and knowledge: local buzz, global pipelines and the process of knowledge creation. Progress in Human Geography, 28(1): 31-56. 
Berger, S. and the MIT Industrial Performance Center (2005) How We Compete. New York: Doubleday.

Borrus, M., Ernst, D., Haggard, S. (eds) (2000) International Production Networks in Asia: Rivalry or Riches? London: Routledge.

Dassbach, C. (1989) Global Enterprises and the World Economy: Ford, General Motors, and IBM, the Emergence of the Transnational Enterprise. New York: Garland Publishing.

Dicken, P. (2003) Global Shift: Reshaping the Global Economic Map in the 21st Century, 4th edn. London: Sage.

Dicken, P. (2004) Geographers and globalization: (yet) another missed boat? Transactions of the Institute of British Geographers, 29: 5-26.

Dicken, P. (2005) Tangled webs: transnational production networks and regional integration. SPACES 2005-04, Phillips-University of Marburg: Germany.

Dicken, P. (2007) Global Shift: Reshaping the Global Economic Map in the 21st Century, 5th edn. London: Sage Publications.

Dicken, P., Kelly, P. F., Olds, K., Yeung, H. W-C. (2001) Chains and networks, territories and scales: towards a relational framework for analysing the global economy. Global Networks, 1: $89-112$.

Dolan, C. and Humphrey, J. (2000) Governance and trade in fresh vegetables: the impact of UK supermarkets on the African horticulture industry. Journal of Development Studies, 37(2): $147-76$.

Dossani, R. and Kenney, M. (2003) Lift and shift; moving the back office to India work in progress (Sept.). Information Technologies and International Development, Vol. 1, No. 2. Cambridge, MA: Massachusetts Institute of Technology, 21-37.

Fold, N. (2002) Lead firms and competition in 'Bi-Polar' commodity chains: grinders and branders in the global cocoa-chocolate industry. Journal of Agrarian Change, 2(2): 228-247.

Gereffi, G. (1994) The organization of buyer-driven global commodity chains: how U.S. retailers shape overseas production networks. In G. Gereffi and M. Korzeniewicz (eds) Commodity Chains and Global Capitalism. Westport: Praeger, 95-122.

Gereffi, G. and Kaplinsky, R. (eds) (2001) The value of value chains: spreading the gains from globalisation. Special issue of the IDS Bulletin, Vol. 32, No. 3. Brighton: University of Sussex.

Gereffi, G., Humphrey, J., Sturgeon, T. (2005) The governance of global value chains. Review of International Political Economy, 12(1): 78-104.

Gertler, M. (2003) Tacit knowledge and the economic geography of context, or the undefinable tacitness of being (there). Journal of Economic Geography, 3: 75-99.

Gibbon, P. (2003) Value-chain governance, public regulation and entry barriers in the global fresh fruit and vegetable chain into the EU. Development Policy Review, 21(5-6): 615-625.

Gibbon, P. and Ponte, S. (2005) Trading Down: Africa, Value Chains, and the Global Economy. Philadelphia: Temple University Press.

Glückler, J. (2007) Economic geography and the evolution of networks. Journal of Economic Geography, 7(5): 619-634.

Granovetter, M. (1985) Economic action and social structure: the problem of embeddedness. American Journal of Sociology, 91: 481-510.

Hall P. and Soskice D. (eds) (2001) Varieties of Capitalism. Oxford, UK: Oxford University Press.

Hansen, G. H. (2008) The far side of international business: local initiatives in the global workshop. Journal of Economic Geography, 8(1): 1-19.

Helper, S. (1991) Strategy and irreversibility in supplier relationships: the case of the U.S. automobile industry. The Business History Review, 65(4): 781-824.

Henderson, J., Dicken, P., Hess, M., Coe, N., Yeung, H. W.-C. (2002) Global production networks and the analysis of economic development. Review of International Political Economy, 9(3): 436-464.

Herrigel, G. (2004) Emerging strategies and forms of governance in high-wage component manufacturing regions. Industry and Innovation, 11(1/2): 45-79.

Humphrey, J. (2003) Globalization and supply chain networks: the auto industry in Brazil and India. Global Networks, 3(2): 121-141. 
Humphrey, J. and Memodovic, O. (2003) The global automotive industry value chain: what prospects for upgrading by developing countries? Sectoral Studies Series. Vienna: United Nations Industrial Development Organization.

Humphrey, J. and Schmitz, H. (2002) How does insertion sn global value chains affect upgrading in industrial clusters. Regional Studies, 36(9): 1017-1027.

Kaplinsky, R. (2005) Globalization, Poverty and Inequality. Cambridge: Polity Press.

Kaplinsky, R. (2006) How can agricultural commodity producers appropriate a greater share of value chain incomes? In A. Sarris and D. Hallam (eds) Agricultural Commodity Markets and Trade: New Approaches to Analyzing Market Structure and Instability. Cheltenham: Edward Elgar and FAO.

Kaplinsky, R., Morris, M. and Readman, J. (2002) The globalization of product markets and immiserizing growth: lessons from the South African furniture industry. World Development, 30(7): 1159-1177.

Korth, K. (2006) Key issues for suppliers: navigating a challenging landscape. Presentation to the Bankruptcy and Receivables Management Workshop, Original Equipment Suppliers Association Regional Meeting, Grand Rapids, Michigan, May 16. Updated 12 February 2008.

Linden, G., Kraemer, K. L., Dedrick, J. (2007) Who Captures Value in a Global Innovation System? The case of Apple's iPod. Personal Computing Industry Center (PCIC) Working paper, June, Irvine: University of California.

Lung, Y., Van Tulder, R., Carillo, J. (eds) (2004) Cars, Carriers of Regionalism? New York: Palgrave Macmillan.

Malmberg, A. and Maskell, P. (1997) Towards an explanation of regional specialization and industry agglomeration. European Planning Studies, 5(1): 25-41.

Markusen, A. (2003) Fuzzy concepts, scanty evidence, policy distance: the case for rigour and policy relevance in critical regional studies. Regional Studies, 37(6 and 7): 701-717.

Martin, R. and Peter, S. (2006) Path dependence and regional economic evolution. Journal of Economic Geography, 6(4): 395-437.

McAlinden, S. P. (2006) There's No Place Like Home; the Geography of Automotive Employment. Presentation at the Chicago Federal Reserve Conference on "The New Geography of Auto Production." April 19, Detroit, MI.

Novak, S. and Wernerfelt, B. (2006) The design of industry, MIT Sloan Research Paper No 460606, March. Available online at: http://ssrn.com/abstract $=891870$.

Pil, F. and Holweg, M. (2006) Evolving from value chain to value grid. MIT Sloan Management Review, 47(4): 72-80.

Saxenian, A. (2006) The New Argonauts: Regional Advantage in the Global Economy. Cambridge, MA: Harvard University Press.

Scott, A. (1998) New Industrial Spaces: Flexible Production Organization and Regional Development in North America and Western Europe. London: Pion.

Storper, M. (1995) The resurgence of regional economies ten years later: the region as a nexus of untraded interdependencies. European Urban and Regional Studies, 2: 191-221.

Storper, M. and Scott, A. (1988) The geographical foundations and social regulation of flexible production complexes. In J. Wolch and M. Dear (eds) The Power of Geography. Boston: Allen and Unwin, 21-40.

Storper, M. and Walker, R. (1989) The Capitalist Imperative: Territory, Technology and Industrial Growth. Oxford: Blackwell.

Sturgeon, T. (2001) How do we define value chains and production networks? IDS Bulletin, 32(3): $9-18$.

Sturgeon, T. (2002) Modular production networks. a new American model of industrial organization. Industrial and Corporate Change, 11(3): 451-496.

Sturgeon, T. (2003) Exploring the risks of value chain modularity: electronics outsourcing during the industry cycle Of 1992-2002. MIT Industrial Performance Center Working Paper 03-002.

Sturgeon, T. (2007) How globalization drives institutional diversity: the Japanese electronics industry's response to value chain modularity. Journal of East Asian Studies, 7(1): 1-34.

Sturgeon, T. (forthcoming) From commodity chains to value chains: interdisciplinary theory building in an age of globalization. In Jennifer Bair (ed.) Frontiers of Commodity Chain Research. Palo Alto, CA, Stanford University Press. Also available as 
MIT Industrial Performance Center Working Paper 08-001 and Sloan Industry Studies Working Paper 2007-41.

Sturgeon, T. and Florida, R. (2004) Globalization, deverticalization, and employment in the motor vehicle industry. In M. Kenny and R. Florida (eds) Locating Global Advantage; Industry Dynamics in a Globalizing Economy. Palo Alto, CA: Stanford University Press.

Sturgeon, T. and Lester, R. K. (2004) The new global supply-base: new challenges for local suppliers in East Asia. In S. Yusuf, A. Altaf and K. Nabeshima (eds) Global Production Networking and Technological Change in East Asia. Washington, DC: The World Bank and Oxford University Press, 35-87.

Sturgeon, T., Van Biesebroeck, J., Gereffi, G. (2007) Prospects for Canada in the NAFTA automotive industry: a global value chain analysis. Research Report, Industry Canada.

Talbot, J. (2002) Tropical commodity chains, forward integration strategies and international inequality: coffee, cocoa and tea. Review of International Political Economy, 9(4): 701-734.

Ward's Automotive Yearbook. (Various years) Southfield, MI: Ward's Communications, Inc.

Whitney, D. (1996) Why mechanical design will never be like VLSI design. Research in Engineering Design, 8: 125-138.

Wolfe, D. A. and Meric, S. G. (2004) Clusters from the inside and out: local dynamics and global linkages. Urban Studies, 41(5 and 6): 1071-1093.

Yeung, H. W., Weidong, L., Dicken, P. (2006) Transnational corporations and network effects of a local manufacturing cluster in mobile telecommunications equipment in China. World Development, 34(3): 520-540. 